\title{
Proposed modification on velocity attenuation relationships in West of Iran with special respect to Dorood fault
}

\author{
Katayoun Behzadafshar,", Abbas Abbaszadeh Shahri' ${ }^{2}$, Mohammad Amin Vares ${ }^{3}$ \\ ${ }^{1}$ Department of Physics, Islamic Azad University, Shahr-e-Rey Branch, Tehran, Iran \\ ${ }^{2}$ Department of Geophysics, Islamic Azad University, Hamedan Branch, Hamedan, Iran \\ ${ }^{3}$ Department of Oil Engineering, Islamic Azad University, Science and Research Branch, Tehrann, Iran
}

\begin{abstract}
As a routine procedure, the estimation of source parameters such as focal mechanism and magnitude is known for moderate to great earthquakes, however some of them such as directivity effect and filing step are rarely taking into account. According to the radiation pattern, directivity effect is a source parameter, which causes significant spatial variations in near field strong ground motion. Its significant variations could be obtained on strike normal component of velocity in forward and backward directions. This study has an attempt on estimation of a modification factor, which can define the effect of directivity in empirical attenuation relationships in Dorood fault. In order to model unilateral and bilateral rupturing Finite Elements Method (FEM) is applied to achieve reliable functions. The authors used Somervill et al. (1997) directivity model parameter with some changes as variable parameter. To obtain modified ground motion parameters, these models were applied for earthquakes which Dorood fault caused them. These parameters consist of fault normal component to fault parallel component of velocity ratio $\left(\mathrm{V}_{\mathrm{n}} / \mathrm{V}_{\mathrm{p}}\right)$ and fault normal component to average horizontal velocity ratio $\left(\mathrm{V}_{\mathrm{n}} / \mathrm{V}\right)$.

It shows $\mathrm{V}_{\mathrm{n}} / \mathrm{V}$ is controlled by directivity angle, distance between the site, epicenter and rupture length. This ratio has the same trend in studied region earthquakes velocity data.
\end{abstract}

Keywords Dorood Fault, Near field, Velocity Attenuation Relationships, Finite Elements Method

\section{Introduction}

Earthquake caused by fault rupturing, starts from epicenter and propagates with the velocity, close to local shear wave velocity as indicated in figure1. This propagation motivates most of rupture energy arrives at the station as a peak pulse in the beginning of the records which represents the accumulated rupture energy effect. Shear wave radiation pattern produced this great pulse, aligned in the strikenormal direction, which is called forward directivity (Douglas et al., 1988). Forward directivity occurs when:

1. Rupture front propagates toward the site.

2. Slipping direction on the fault is aligned with the site. Backward directivity occurs when the rupture front propagates away from the site. It causes long duration motions with low amplitudes at long periods (Somervill et al., 1997). Some of the previous studies about this phenomenon are indicated in table (1).

* Corresponding author:

k. behzadafshar@srbiau.ac.ir (Katayoun Behzadafshar)

Published online at http://journal.sapub.org/jce

Copyright (C) 2012 Scientific \& Academic Publishing. All Rights Reserved

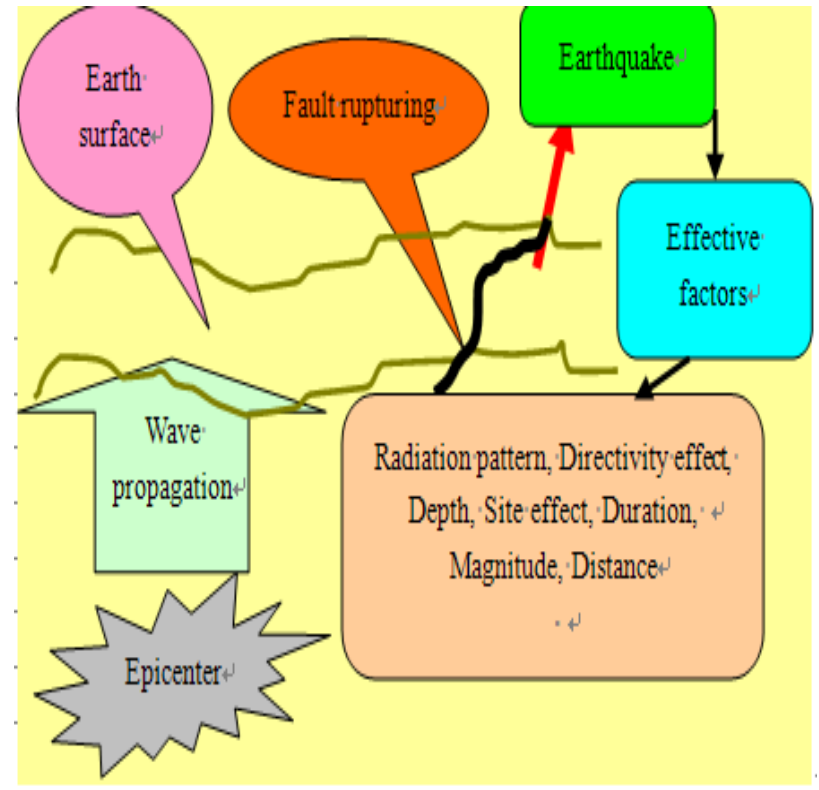

Figure 1. Earthquake and effective parameters

In this study, the finite element method was performed to propose a model for Silakhor earthquake (Iran, 2006, $\mathrm{M}_{\mathrm{w}} 6.1$ ) 
by using ANSYS software and the directivity effect on strong ground motion was evaluated. By taking into account of this fact that directivity effects are often on strike normal

component, the authors were focused on the ratios of strike normal to strike parallel strong ground velocity and strike normal to average horizontal strong ground velocity, by consideration of dista pnce, rupture length and directivity angle. Therefore, a function as a directivity coefficient is defined to account in horizontal component of peak ground velocity attenuations relationships.

Table 1. Previous study about the directivity effect

\begin{tabular}{|c|c|c|}
\hline Researcher (s) & Case study & Obtained results \\
\hline Benioff (1955) & $\begin{array}{c}\text { Introduced directivity } \\
\text { effect }\end{array}$ & $\begin{array}{l}\text { Explained the increase of } \\
\text { strong motion amplitude in } \\
\text { forward and its decrease in } \\
\text { backward direction. }\end{array}$ \\
\hline Haskell (1969) & $\begin{array}{l}1966 \text { Park field } \\
\text { earthquake accelero- } \\
\text { graphs }\end{array}$ & $\begin{array}{l}\text { Obtained differences be- } \\
\text { tween strike normal ground } \\
\text { motion amplitude in for- } \\
\text { ward and backward direc- } \\
\text { tions. }\end{array}$ \\
\hline $\begin{array}{l}\text { Bullen and } \\
\text { Bolt (1985) }\end{array}$ & & $\begin{array}{l}\text { Introduced the directivity } \\
\text { effect at shear wave radia- } \\
\text { tion pattern in frequency } \\
\text { domain. }\end{array}$ \\
\hline $\begin{array}{l}\text { Boatwright } \\
\text { (1982) }\end{array}$ & $\begin{array}{c}1980 \text { Livermore } \\
\text { earthquake accelero- } \\
\text { graphs }\end{array}$ & $\begin{array}{l}\text { 1. Neglecting the site ef- } \\
\text { fect, strong motion is in- } \\
\text { fluenced by directivity } \\
\text { even more than } 10 \text { times. } \\
\text { 2. Directivity mostly ef- } \\
\text { fects on strong ground } \\
\text { velocity. }\end{array}$ \\
\hline $\begin{array}{l}\text { Somervill et al. } \\
\text { (1997) }\end{array}$ & & $\begin{array}{l}\text { 1. Represented directivity } \\
\text { effect on acceleration } \\
\text { spectrum, duration of } \\
\text { acceleration and strike } \\
\text { normal to strike parallel } \\
\text { acceleration ratio. } \\
\text { 2. Proved that the directiv- } \\
\text { ity effect is more noticeable } \\
\text { at periods longer than } 6 \mathrm{~s} \text {. }\end{array}$ \\
\hline $\begin{array}{l}\text { Aagaard et al } \\
\text { (2004) }\end{array}$ & $\begin{array}{l}1991 \text { Chi-chi earth- } \\
\text { quake }\end{array}$ & $\begin{array}{l}\text { Used finite element method } \\
\text { (IDEAS Software) }\end{array}$ \\
\hline
\end{tabular}

\section{Silakhor Earthquake (Iran, 2006)}

This event was reported by national seismographic network and international agencies as indicate in table (2) and recorded by 15 digital accelerograms as their features illustrates in table (3).

Harvard Centroid Moment Tensor solution (CMT) determined the strike slip focal mechanism with normal component for this event. Pakzad and Mirzaei (2007) obtained the same result by linear inversion of moment tensor in time domain.

Dorood fault is known as the most important seismic segment of Main Zagros Recent Fault, which is defined as 2006 Silakhor earthquake seismic source. However the fault with strike of $313^{\circ}$ and NW-SE trend has more than $100 \mathrm{~km}$ length, but just $44 \mathrm{~km}$ of it ruptured unilaterally from southeast to northwest during this earthquake (Pakzad and Mirzaei, 2007). Figure2 shows the regional faults, epicenter and focal mechanism of the event.

Table 2. Silahkor earthquake reported by agencies.

\begin{tabular}{|c|c|c|c|}
\hline \multirow{2}{*}{ Agency } & \multirow{2}{*}{ Magnitude } & \multicolumn{2}{|c|}{ Epicentral coordination } \\
\cline { 3 - 4 } & 5.9 & $33.48^{\circ}$ & $48.86^{\circ}$ \\
\hline $\begin{array}{c}\text { Institute of Geophysics, } \\
\text { Tehran University }\end{array}$ & 5.1 & $33.62^{\circ}$ & $47.9^{\circ}$ \\
\hline IIEES & 6.1 & $33.58^{\circ}$ & $48.94^{\circ}$ \\
\hline U. S. Geological Survey & 6.1 &
\end{tabular}

Table 3. Feature of recording stations (Mirzaei Alavijeh et al, 2006).

\begin{tabular}{|c|c|c|c|c|c|}
\hline \multirow{2}{*}{$\begin{array}{c}\text { Installment } \\
\text { angle }\end{array}$} & \multirow{2}{*}{$\begin{array}{c}\text { Instru- } \\
\text { ment } \\
\text { type }\end{array}$} & \multicolumn{2}{c|}{ Location } & \multirow{2}{*}{ Station } \\
$n$ & $\mathrm{~T}$ & $\mathrm{E}$ & \\
\hline 5 & 95 & SSA-2 & 33.58 & 48.26 & Aleshtar \\
\hline 71 & 161 & SSA-2 & 33.78 & 48.62 & $\begin{array}{c}\text { Kushk-e-Ab-e- } \\
\text { Sard }\end{array}$ \\
\hline 230 & 320 & SSA-2 & 34.55 & 48.42 & Touyserkan \\
\hline 59 & 149 & SSA-2 & 33.65 & 48.91 & Chalan choulan \\
\hline 110 & 200 & SSA-2 & 33.63 & 48.55 & Chghalvandi \\
\hline 45 & 315 & SSA-2 & 34.40 & 49.15 & Khondab \\
\hline 29 & 119 & SSA-2 & 33.45 & 49.06 & Dareh Absar \\
\hline 215 & 305 & SSA-2 & 33.46 & 49.07 & Dorood \\
\hline 22 & 112 & SSA-2 & 43.17 & 48.24 & Giyan \\
\hline 207 & 298 & SSA-2 & 34.21 & 48.70 & Samen \\
\hline 20 & 110 & SSA-2 & 33.21 & 48.89 & Sepid dasht \\
\hline 175 & 265 & SSA-2 & 33.93 & 49.40 & Shazand \\
\hline 210 & 300 & SSA-2 & 33.2 & 49.18 & Shoul abad \\
\hline 300 & 30 & SSA-2 & 34.68 & 48.74 & Gonbad \\
\hline 215 & 305 & SSA-2 & 34.36 & 48.11 & Firouzan \\
\hline 20 & 110 & SSA-2 & 34.30 & 48.80 & Malayer \\
\hline 156 & 246 & SSA-2 & 34.06 & 47.97 & Nour abad \\
\hline 92 & 192 & SSA-2 & 34.18 & 48.37 & Nahavand \\
\hline
\end{tabular}

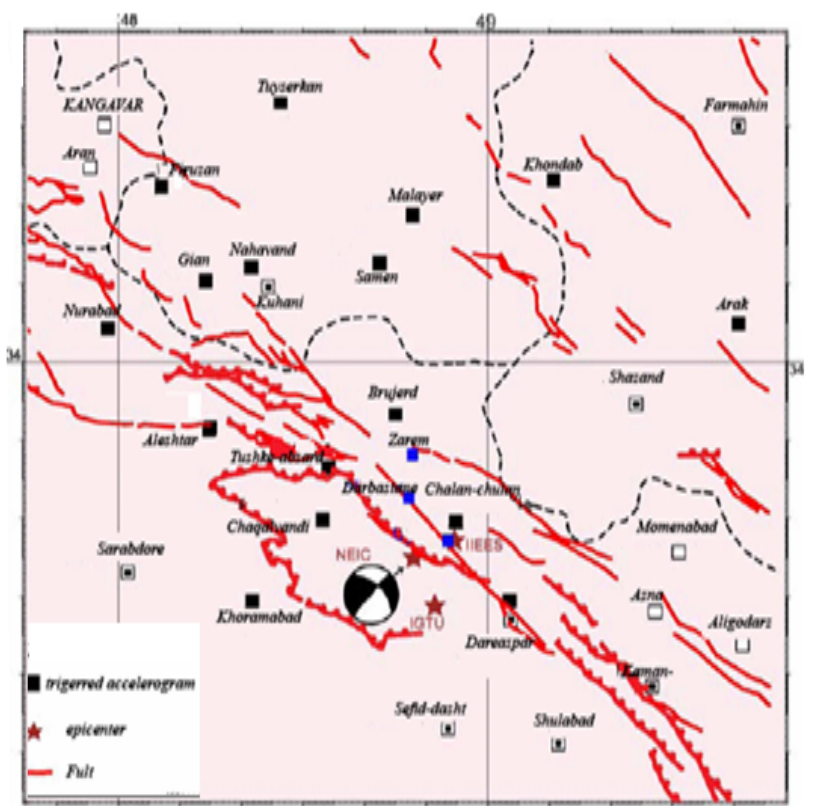

Figure 2. Dorood region faults, epicenter and focal mechanism (NEIC) 2006 Silakhor earthquake (Mirzaei Alavijeh et al, 2006) 
By consideration of accelerograms distance to epicenter, northwest of the epicenter have larger amplitudes than those located on southwest. For instance, maximum acceleration amplitude, recorded by Dorood station (southeast of epicenter) with $31 \mathrm{~km}$ distance, is $0.379 \mathrm{~g}$, while Kushk-e-Ab-e-Sard station (northwest of epicenter) with 42 $\mathrm{km}$ distances, recorded $0.394 \mathrm{~g}$ as maximum acceleration amplitude, which is present in figure3. Regarding to 2006 Silakhor focal mechanism (right strike slip), the rupture directivity is toward northwest, and therefore directivity effect causes larger acceleration amplitudes in northwest of epicenter station.

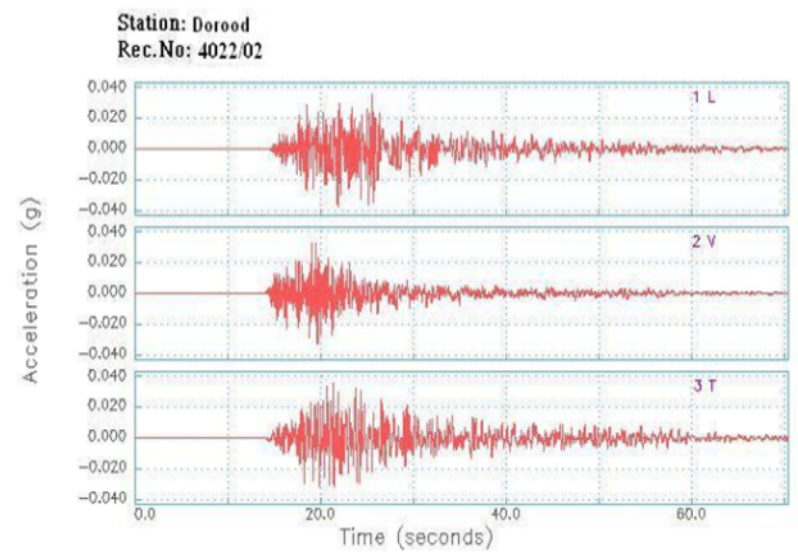

Station: Kooshk-e-Ab-e-Sard Rec.No: 4035/03

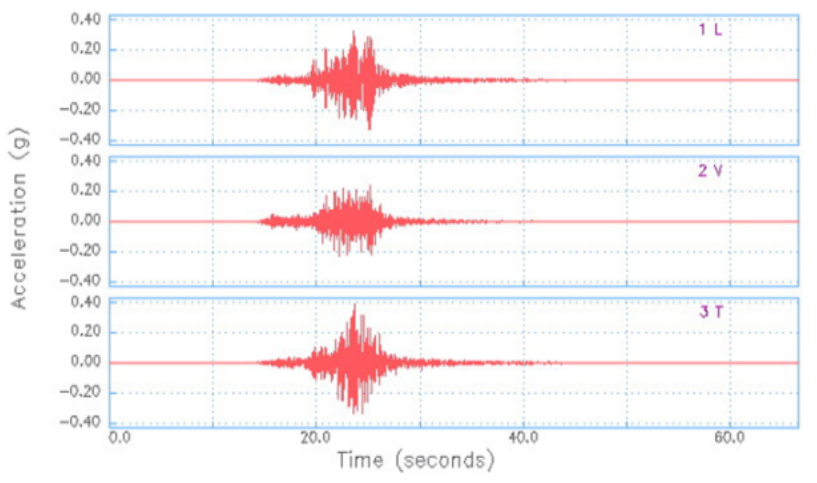

Figure 3. Recorded accelerograph at Dorood and Kushk-e-Ab-e-Sard stations (Behzadafshar, 2008)

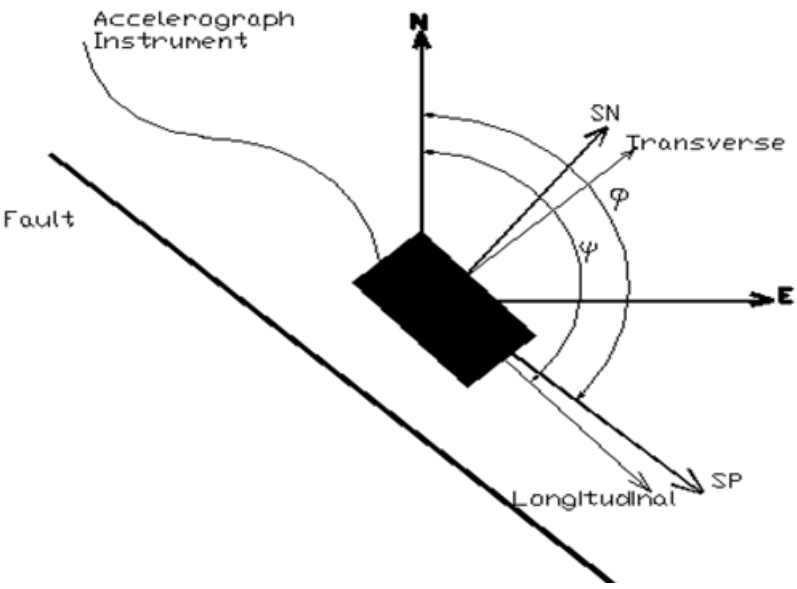

Figure 4. Rotation in to fault normal (SN) and fault parallel (SP) com- ponent (Kenneth and South, 2002)

\section{Accelerograph Correction}

In this study the by use of Seismosignal the base line correction and filtering of the recorded acceleroghraphs were executed. As mentioned before, because of directivity affects on fault normal components, the recorded accelerographs should be rotated into normal and parallel direction of Dorood fault strike. By refer to figure4; equation (1) is used for rotation into normal and parallel fault strike directions (Kenneth and South, 2002):

$$
\begin{aligned}
& S P=N \cos (\phi-\psi)+E \sin (\phi-\psi) \\
& S N=-N \sin (\phi-\psi)+E \sin (\phi-\psi)
\end{aligned}
$$

Where; $\mathrm{SP}=$ fault strike parallel component, $\mathrm{SN}=$ fault strike normal component, $\varphi=$ fault strike and $\psi$ is azimuthally angle of accelerograph installment.

\section{Earthquake data and analysis}

The variation of maximum $\mathrm{V}_{\mathrm{n}} / \mathrm{V}_{\mathrm{p}}$ ratio on base of directivity angle $(\theta)$, which represents radiation pattern, is presented in figure5. This ratio increases in both forward and backward directions; however, it is larger in forward direction and equation (2) has obtained from trend line of this figure. It shows the relation between 2006 Silakhor event $\mathrm{V}_{\mathrm{n}} / \mathrm{V}_{\mathrm{p}}$ ratio by directivity angle.

$$
\frac{V_{n}}{V_{p}}=5 \times 10^{-5} \theta^{2}-0.0094 \theta+1.2611\left(R^{2}=0.36\right)
$$

Variation of $\mathrm{V}_{\mathrm{n}} / \mathrm{V}$ ratio on base of $\theta$ is shown in figure 6. It indicates that the ratio increases in both forward and backward directions. Equation (3) pointed the variation of $V_{n} / V$ ratio by directivity angle from Silakhor.

$$
\frac{V_{n}}{V}=2 \times 10^{-5} \theta^{2}-0.0045 \theta+0.8797 \quad\left(R^{2}=0.45\right)
$$

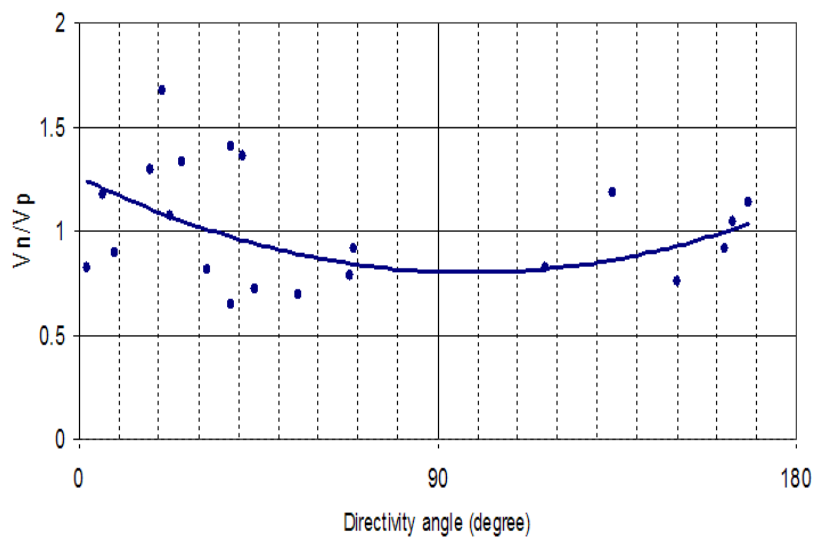

Figure 5. Maximum ratio of $\mathrm{V}_{\mathrm{n}} / \mathrm{V}_{\mathrm{p}}$ for Dorood fault, by directivity angle (2006 Silakhor earthquake)

\section{Directivity Modeling by Finite Element Method (FEM)}


Simulation of rupture directivity by FEM is applied to define the directivity coefficient, which should be accounted in velocity attenuation relationships. At the first step and by the suggested Aagaard et al (2004) algorithm, the earthquake was modeled by ANSYS. It is necessary to note the following:

$\checkmark$ Modeling the rupture zone in ANSYS

$\checkmark$ Exercise rupturing at modeled fault to provide strong ground motion and determination of them at same distance but different directivity angles

$\checkmark$ Directivity function representation

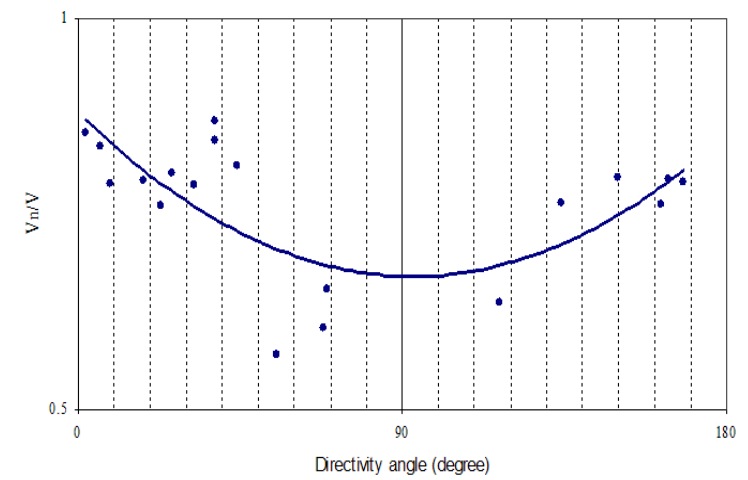

Figure 6. Maximum ratio of $\mathrm{V}_{\mathrm{n}} / \mathrm{V}$ for Dorood fault, by directivity angle (2006 Silakhor earthquake)

\section{Directivity Model Parameters}

As shown in figure7, Somervill et al. (1997) identified directivity angle $(\theta)$ and $X$ [the ratio of rupture length (s) to fault length $(\mathrm{L})$ ] as directivity model parameters and they chose $\mathrm{X} \operatorname{Cos} \theta$ as an independent parameter to evaluate directivity effect. Based on figure6, these parameters can be written as:

$$
X \cos \theta=\frac{s}{L} \cos \theta=\left(\frac{R}{L}\right) \cos ^{2} \theta
$$

Where, $\mathrm{R}$ is closest distance between site and epicenter. In the case of study on uncertain rupture length, $\mathrm{X}$ can be defined by $\mathrm{L}$ and $\mathrm{R}$.

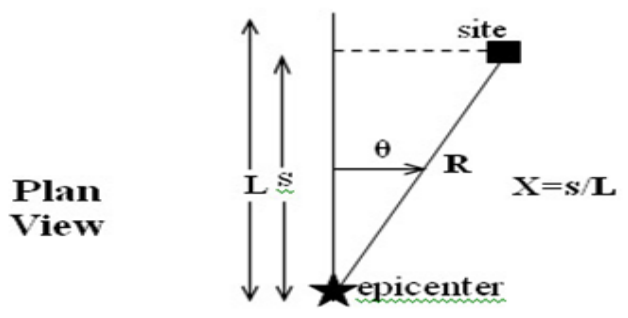

fault

Figure 7. Directivity parameters for strike slip faulting (Somervill et al, 1997)

\section{Comparison of Silakhor Earthquake and Modeled Data}

Figure8 illustrates the variations of $\mathrm{V}_{\mathrm{n}} / \mathrm{V}_{\mathrm{p}}$ ratio on base of $\theta^{\circ}$ for silakhor and its modeled earthquake. According to shear wave radiation pattern and directivity effect, it can be seen that in forward direction, $V_{n}$ increases where as $V_{p}$ decreases, and the ratio of $\mathrm{V}_{\mathrm{n}} / \mathrm{V}_{\mathrm{p}}$ is largest in forward direction $(\mathrm{Vn} / \mathrm{Vp}=1.76)$. In perpendicular direction to the fault strike $\left(\theta=90^{\circ}\right)$ increase of $\mathrm{Vn}$ and decrease of $\mathrm{V}_{\mathrm{p}}$ cause slump in $\mathrm{V}_{\mathrm{n}} / \mathrm{V}_{\mathrm{p}}$ ratio $\left(\mathrm{V}_{\mathrm{n}} / \mathrm{V}_{\mathrm{p}}=0.75\right)$. It can be seen the $\mathrm{V}_{\mathrm{n}} / \mathrm{V}_{\mathrm{p}}$ ratio $\left(\mathrm{V}_{\mathrm{n}} / \mathrm{V}_{\mathrm{p}}=1.58\right)$ from directivity angle $90^{\circ}$ to $180^{\circ}$. Directivity effect provides asymmetry in $\mathrm{S}$ wave radiation pattern (Lay and Wallace, 1995), which is obvious in forward and backward directions. $\mathrm{V}_{\mathrm{n}} / \mathrm{V}_{\mathrm{p}}$ ratio in forward is larger than backward and is shown in figure8. Equation (5) shows the variation of $\mathrm{Vn} / \mathrm{Vp}$ ratio by $\theta$ which is obtained from the modeling.

$$
\frac{V_{n}}{V_{p}}=0.0001 \theta^{2}-0.0239 \theta+1.8687 \quad\left(R^{2}=0.69\right)
$$

These two diagrams have good correlations together. According to $\mathrm{S}$ wave radiation pattern, the authors expected equality of $V_{n}$ and $V_{p}$ at $45^{\circ}$ directivity angle. It shows this equality at $50^{\circ}$ directivity angle, which indicates accuracy in both Silakhor earthquake and modeling data analysis. By refer to figure8, $V_{n} / V_{p}$ ratio soars both in forward and backward directions. Minimum value at $90^{\circ}$ directivity angle (perpendicular to the fault strike) indicates increase of $\mathrm{V}_{\mathrm{p}}$ at $90^{\circ}$ directivity angle, whereas $\mathrm{V}_{\mathrm{p}}>\mathrm{V}_{\mathrm{n}}$. So briefly, it can be said that the ratio of $\mathrm{V}_{\mathrm{n}} / \mathrm{V}_{\mathrm{p}}$ is controlled by $\theta$.

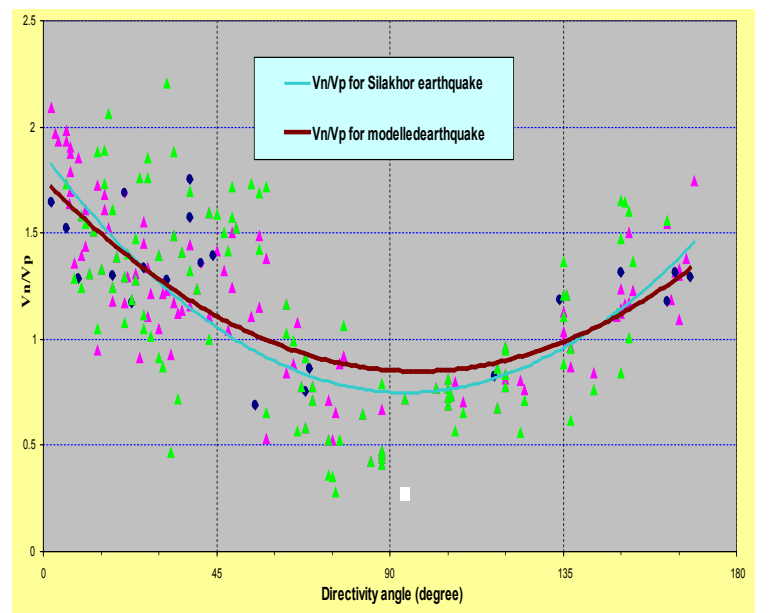

Figure 8. Maximum of $\mathrm{V}_{\mathrm{n}} / \mathrm{V}_{\mathrm{p}}$ ratio, by directivity angle for Silakhor earthquake and it's modeling.

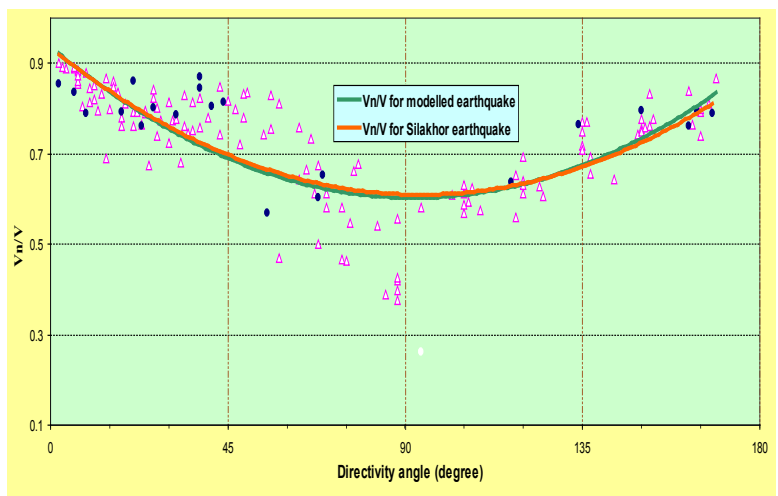

Figure 9. Maximum of $\mathrm{V}_{\mathrm{n}} / \mathrm{V}$ ratio, by directivity angle for Silakhor earthquake and it's modeling. 
By refer to figure9, in forward direction; $\mathrm{V}_{\mathrm{n}}$ increase causes to reach the peak of $\mathrm{V}_{\mathrm{n}} / \mathrm{V}$ ratio (around one). This increase is also clear in backward but it is less than forward. Minimum amount of $\mathrm{V}_{\mathrm{n}} / \mathrm{V}$ is happened in $\theta=90^{\circ}\left(\mathrm{V}_{\mathrm{n}} / \mathrm{V}=0.6\right)$, which has a good fitting condition with radiation pattern in strike slip faulting as indicated in figure10. In equation (6) the variation of $\mathrm{V}_{\mathrm{n}} / \mathrm{V}$ by $\theta$, is obtained for 2006 Silakhor earthquake modeling.

$$
\frac{V_{n}}{V}=4 \times 10^{-5} \theta^{2}-0.0073 \theta+0.9388 \quad\left(R^{2}=0.71\right)
$$

It can be seen, these two diagrams coincide well. In both diagrams increase of $V_{n} / V$ ratio in forward and backward directions and decrease of $\mathrm{V}_{\mathrm{n}} / \mathrm{V}$ at $\theta=90^{\circ}$ signifies directivity effect on strike normal component of velocity.

Figure11 shows the variation of $\mathrm{V}_{\mathrm{n}} / \mathrm{V}$ ratio against the $(R / L) \operatorname{Cos}^{2} \theta$. Equation (7) defines this variation, which is obtained from this figure. Maximum value happens for the stations in forward direction $\left(\theta=0^{\circ}\right)$. At the end of the fault $(\mathrm{R}=\mathrm{L})$ the $(\mathrm{R} / \mathrm{L}) \operatorname{Cos} 2 \theta$ will reach to one in forward direction. Equation (7) indicates that at distance $R \leq L$ directivity effect soars by increase of $R$ up to the end of the fault, where $\mathrm{R}$ equals to $\mathrm{L}$. Then at distance $\mathrm{R}>\mathrm{L}$, decrease of directivity effect due to $\mathrm{R}$ increasing can be seen. Therefore, equation (7) is not reliable for $\mathrm{R}>\mathrm{L}$.

$$
\begin{aligned}
& \frac{V_{n}}{V}=-0.2324 \cdot\left(\frac{R}{L} \cdot \operatorname{Cos}^{2} \theta\right)^{2}+0.5402 \cdot\left(\frac{R}{L} \cdot \operatorname{Cos}^{2} \theta\right)+0.5509 \\
& \left(R^{2}=0.57\right) \quad \text { For } R \leq L
\end{aligned}
$$
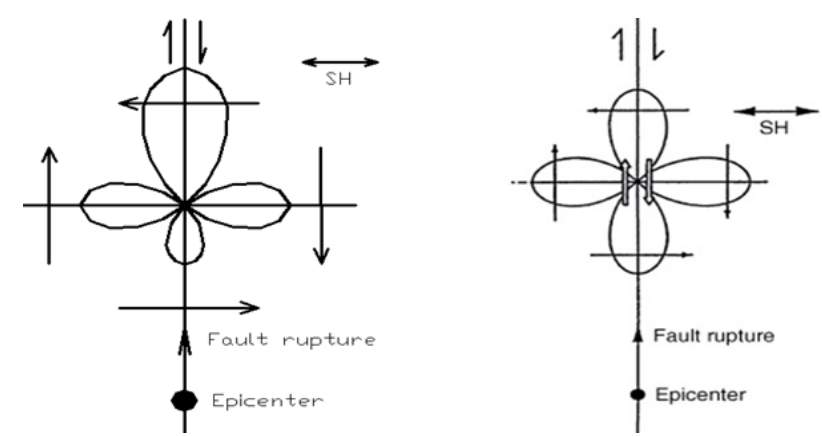

Figure 10. Radiation pattern for strike slip faulting Right: For point source (Lay and Wallace, 1995) Left: For unilateral rupturing (from south to north) (Somervill et al, 1997).



Figure 11. Maximum modeled $\mathrm{V}_{\mathrm{n}} / \mathrm{V}$ ratio, by $(R / L) \operatorname{Cos}^{2} \theta$

\section{Conclusions}

Considering to more effect of directivity on strike normal component, variation of maximum strike normal to strike parallel velocity ratio by directivity angle is defined. It indicates increase of $V_{n} / V_{p}$ in forward and backward directions as we expect from strike slip fault radiation pattern. Directivity effect on strike-normal component causes minimum of this ratio at $90^{\circ}$ directivity angle.

It can be seen that the increase of $\mathrm{V}_{\mathrm{n}} / \mathrm{V}$ in forward and backward directions and decrease of this value in $90^{\circ}$ directivity angle. It happens due to directivity effect, and both 2006 Silakhor earthquake and its modeling confirm these results. We apply $(R / L) \operatorname{Cos}^{2} \theta$ to account distance, rupture length and directivity angle in our study. The results represents at distance less than or equal to rupture length $(R \geq L)$ the ratio soars by distance increasing. It indicates directivity phenomena, effects more by $\mathrm{R}$ increasing in distance of $\mathrm{R}<\mathrm{L}$. Maximum directivity effect happens at the end of the fault, where $\mathrm{R}=\mathrm{L}$. Silakhor earthquake and earthquake modeling state that it is necessary to apply equation 7 to account directivity effect in velocity attenuation relationships in near field. It is useful to achieve more reliable results in near field studies.

\section{REFERENCES}

[1] Aagaard, B., Hall, J. and Heaton, T., 2004, Effect of Fault Dip and Slip Angles at Near- Source Ground Motions: Why Rupture Directivity Was Minimal in the 1999 Chi-Chi, Taiwan Earthquake, Bull. Seism. Soc. Am., (94): 155-170

[2] Behzadafshar, K., 2008, Study of directivity effect on PGV attenuation relationships, Ph.D thesis, Science and Research branch of IAU, Tehran, Iran

[3] Benioff, M.,1955, Mechanism and Strain Characteristics of the White Wolf Fault as Indicated by the Aftershock, Sequence, Calif., Div. Mines Bull.,171, 199-202

[4] Boatwright, J., 1982. A Dynamic Model for Far-Field Acceleration, Bull., Seism. Soc. Am., (73):1049- 1069

[5] Bullen, K. E. and Bolt, B. A., 1985, An Introduction to the Theory of Seismology, $4^{\text {th }}$ ed., Cambridge University Press, Cambridge, England

[6] Douglas, A., Hudson, J. A. and Pearce, R.G., 1988, Directivity and Doppler Effect, Bull., Seism. Soc. Am., (78): $1367-$ 1372

[7] Haskell, N.A., 1969, Elastic Displacements in the Near-Field of a Propagating Fault, Bull., Seism. Soc. Am., (59): 865-908

[8] Kenneth, E.C., South, A.A., 2002, Characterization of Large Velocity Pulse for Laboratory Testing, PEER Report 2002/22, Pacific Earthquake Engineering Research Center, Collage of Engineering, University of California, Berkeley

[9] Lay, T. and Wallace, T.C., 1995, Modern Global Seismology, Academic Press. California

[10] Pakzad, M. and Mirzaei, N., 2007, Study on focal mechanism of March 31th 2006 Darbe Astaneh-Silakhor earthquake, 
Jurnal of physics of the earth and space, Vol. 33-3, pp. 73-86

[11] Somervill, P., Smith, N., Graves, R. and Abrahamson, N., 1997, Modification of Empirical Strong Ground Motion Attenuation Relation to Include the Amplitude and Duration
Effects of Rupture Directivity, Seism. Res.Let., 68, 199-222

[12] Mirzaei Alavijeh, H. Farzanegan, A., Majedi Ardakani, M. H. and Sinaeian, F., 2006, Report of 31th March 2006 Silakhor earthquake, Building and Housing Research Center 